Article

\title{
Scrambling for the Centre: Ghana's New Churches as an Alternative Ideology and Power
}

\author{
Michael Perry Kweku Okyerefo ${ }^{1,2}$ \\ 1 Department of Sociology, University of Ghana, Legon P. O. Box LG 65, Ghana; mokyerefo@ug.edu.gh \\ 2 Critical Studies in Higher Education Transformation (CriSHET), Nelson Mandela University, 14 Bird Street, \\ Port Elizabeth 6001, South Africa
}

Received: 30 September 2019; Accepted: 9 December 2019; Published: 12 December 2019

\begin{abstract}
The effort expended by religious groups in Ghana to access and influence political power is not a historic novelty. Most clearly manifested in organizational strategies and the pronouncements of religious leaders, sectional ambitions in respect of political access and influence have recently gained ascendancy in response to the relatively rapid and large-scale growth of religious diversity across the nation and within its growing conurbations. This scramble for access and influence has also been fueled by the overt participation of some political leaders in religious activities, which are perceived to grant certain groups an enviable presence in the public sphere and favoured access to the corridors of state power. Focusing on two of Ghana's New Churches, both Pentecostal-charismatic organizations, as case studies, this paper explores the strategies and motivations of religious groups striving to access and influence political society in an increasingly diverse socio-cultural context.
\end{abstract}

Keywords: Ghana's New Churches; ideology; dominant ideology; alternative ideology; political power

\section{Introduction}

In spite of notions of church-state separation, religion and politics have had and continue to have a perennial relationship globally. Examples of this include the Catholic Church, which has long had and still wields supranational political influence, and forms of political Islam that have been attracting followers globally. In the democratic United Kingdom, the Anglican Church still constitutes a national church with the monarch as Head, and other individuals such as the late Billy Graham and Oral Roberts have had considerable political influence in the United States. Dovlo (2005, p. 629) has pointed out that in Ghana, specifically, as in British West Africa in general, religious influence was not expunged from the traditional public sphere by British colonial rule, since the British principle of "indirect rule" involved traditional rulers in the colonial power structure. "Colonial rule established the modern state and with it a new relationship between the state and religion", such that although "Ghana was conceived as a secular state, Christianity was identified with colonial rule because it was the religion of the Colonizers". Consequently, "English common law, with its Judeo-Christian foundations, buttressed many new laws that guided the State during that period", just as "Islamic law also influenced the development of law, especially family law".

Consequently, the Ghana Catholic Bishops' Conference (GCBC), the Christian Council of Ghana (CCG), and the Ghana Pentecostal and Charismatic Council (GPCC) all exert enormous political and moral influence on the Ghanaian polity. More recently, some of the new Pentecostal-charismatic churches and their leaders in Ghana, notably Pastor Mensa Otabil of the International Central Gospel Church (ICGC) and Archbishop Duncan-Williams of the Christian Action Faith Ministries International (Action Chapel), have also been increasingly influential politically. 
In addition, there is a long history in Africa regarding the link between the spiritual and the material (Hastings 1994, pp. 275-78), which shapes religious leaders' influence in the public sphere. The channels thorough which such influence has been exerted in Ghana include the social institutions that religious groups establish, such as schools and hospitals, as well as the pronouncements of religious leaders on national issues. In recent times, the state has involved religious leaders in the National Peace Council, for example, which is critical in fostering peace within a hotly contested political terrain, especially during democratic elections, while religious bodies have taken it upon themselves to observe elections, for instance, to ensure their credibility and foster peace in the country.

While both Muslim leaders and those of the historic mission churches have been at the vanguard of this development, the religious landscape is changing, featuring the newcomers-the Pentecostal-charismatic churches-prominently, obviously as a result of the sheer growth in their membership and institutionalization (Okyerefo 2011). Pentecostal-charismatic leaders, such as Archbishop Duncan-Williams and Pastor Mensa Otabil, have thus been emboldened and feel they have a responsibility and a mandate to contribute to shaping public discourse and the political and economic processes. Adding to their growth is their wealth and blatant opulence, as well as the increasing popularity of these churches, which count some prominent citizens, including politicians, among their membership. All these developments point to the relationship between religion and politics in Ghana at this momentous epoch, within which broad framework the activities of the Pentecostal-charismatic churches should be understood and within which both Pastor Mensa Otabil's and Archbishop Duncan-Williams' nibbling at the centre of power will be examined.

Archbishop Duncan-Williams founded Action Chapel in 1979, while Pastor Mensa Otabil founded the ICGC in 1984. They both constitute the oldest Pentecostal-charismatic churches in Ghana, each with a sizable following in Ghana and with branches elsewhere in Africa and overseas (Okyerefo 2008, 2011, 2014). Without conflating the Pentecostal and charismatic traditions, with the former placing emphasis on the Pentecost experience and the latter on individuals' possession of the gifts of the spirit (charismata), it is observable that the boundaries of such a strict delineation are blurred in many of Ghana's new churches, hence the description "Pentecostal-charismatic". Huaco (1971, p. 249) has observed that "Marx's analysis of religion as a pseudo-control of the environment is an account of ideology as a compensatory symbolic response to stress". Social class struggle is certainly stressful to many in Ghana, and the "compensatory ideology" (Huaco 1971, p. 249) provided by Pentecostalism has assisted Ghanaians as they seek ways to navigate it. Arguably, the status of these two pioneering Pentecostal-charismatic churches have enabled their members to traverse the social class configuration in Ghana, and this has also given them a powerful alternative voice; i.e., a voice other than that of the state apparatus in politics.

This paper interrogates the Ghanaian media's depictions of Pastor Mensa Otabil and Archbishop Duncan-Williams, and also how they are viewed by some members of their churches interviewed for this study. The paper is a descriptive narrative of the strategies and pronouncements of these religious leaders of the two pioneering Pentecostal-charismatic churches in Ghana to underscore their alternative ideology within a broader discussion of the separation of church and state in democratic Ghana (Dovlo 2005).

\section{Religion and Politics in Ghana}

Religion is visibly ubiquitous in the Ghanaian public sphere. This is perhaps not surprising, given the growth of religious groups in the country. In 2000, 68.8\% of the 19 million population of Ghana were Christian, $15.9 \%$ Muslim, 8.5\% Traditional Religious Adherents, and 6.1\% reported affiliation with no religion (Ghana Statistical Service 2002). Ten years on, the 2010 Population and Housing Census Report indicated that $71.2 \%$ of the 24.6 million Ghanaian population profess the Christian faith, $17.6 \%$ Islam, 5.2\% traditional religion, and 5.3\% were not affiliated to any religion (Ghana Statistical Service 2002, p. 6). The Pentecostal-charismatic churches form a salient part of this religious map, together making up $28.3 \%$ of the population (Ghana Statistical Service 2012, p. 40). 
Apart from the increasing construction of church edifices and mosques throughout the country, megachurches in particular continue to dot the urban skyline. Interestingly, a good number of the said churches have taken over the premises of collapsed industries, making the churches a symbolic representation of their failure. For example, the premises of Domalong Steel Company and Paramount Distilleries have been taken over by Royalhouse Chapel, while those of the Meat Marketing Board and Willowbrook Ghana have been taken over by Perez Chapel. In the same vein, Action Chapel today occupies land that President Kwame Nkrumah zoned into a light industrial area south of the Accra-Tema motorway. Moreover, the visibility of religion in Ghana goes beyond architectural structures and the display of religious activity by worshipers to the rather open discussion of religion in the media amidst a growing presence of religious leaders who ostentatiously seek to influence political culture in the country. As observed earlier, this is not unique to Ghana and its Pentecostal-charismatic churches; however, being new players in the field compared to the historic mission churches, the success of these churches in the influence they exert on the Ghanaian public sphere is remarkable and worthy of sociological analysis.

The December 2012 elections in Ghana were perhaps the most contested in the nation's recent democratic dispensation. Apart from the main opposition National Patriotic Party (NPP) challenging the election results in court, the electioneering campaign prior to the elections was itself fraught with acrimony to the point where even an individual person, Pastor Otabil, felt he was under attack. In other words, even without professing to be a politician, Pastor Otabil felt undue advantage was taken of him by a cross-section of the political spectrum for political gain. On 12 November 2012, he called a press conference to address what he said were "media references that seek to place my sermons and me in a partisan political position". His objective, he said, was "to clarify some misrepresentations of my sermons and to hopefully stop the running harassment against my integrity" (Otabil 2012).

Before addressing the main issue, however, Pastor Otabil seized the opportunity to spell out what great service he and his church have rendered to Ghana by operating "one of the largest non-governmental educational scholarship schemes in the country", providing "several needy people and communities with help", such as "portable water to people living in Buruli-ulcer endemic area", and building "a fully furnished boys dormitory for the Osu Children's home". He said the ICGC was "probably the largest private donor to the Children's Cancer unit of the Korle-Bu Teaching Hospital", and his "church operates the largest private university in Ghana with almost 10,000 students". In his own words, this service to his country emanates from the "spirit of generosity that was shown" him and his siblings in their "days of despair" as orphans. He sees himself as "a bridge builder", his ministry consisting in encouraging all people, "Christians of all shades, Muslims and a large segment of people who belong to different belief systems" (See Okyerefo 2018, 2011; De Witte 2003 for examples of the many works of Otabil and his church's business).

Pastor Otabil was blatantly insistent: "I am a pastor. I am not a politician. I am not standing for any political office. I am not a member of any political party". His complaint was that his "voice and sermons have been sampled, spliced and manipulated to appear to take a political position on a very heated political issue". He further stated: "I have also been made to appear as taking a stand against one political group or the other". He decided not to keep silent as he claimed he would normally do because he realised he "was dealing with a marauding and bullying force that was bent on impugning' his 'name and integrity without shame". His pulpit, he said, is not for partisan politics. Rather, his "messages have consistently spoken to the larger issues of hope, righteousness and justice". To this end, he called the acts of misrepresenting his sermons "defamatory", "unethical", "criminal", "malicious", "Machiavellian", and "evil", "a violation of my person and my integrity", calling on "all men and women of conscience" to resent it, "all people of faith—Christians and Moslems, Pastors and Imams—to demand for righteousness, justice and fairness in our national discourse", and "the President of the Republic to rise up and speak on this issue" as "the perpetrators of these blatant acts of impunity are largely affiliates and surrogates of your party". 
On the one hand, this incident concerns an individual citizen seeking to exercise his right of freedom of speech to address what he considers an unjust treatment of his person. On the other hand, pronouncements of pastors of the stature of Mensa Otabil, as the one reported above by the media, are not mere individual overtures. They are directed at the public sphere to a political effect as poignantly visible in the above discourse. Any individual can call a press conference in a democracy; the question is whether the press will show up, and they did in this case as he had been misquoted. The response of the press is indicative of the moral authority Pastor Otabil wields in the Ghanaian public sphere even to a political effect. To this end, this paper examines the strategies and motivations that Pentecostal-charismatic religious groups, such as his and Archbishop Duncan-Williams' group, employ to access and influence political society in an increasingly diverse socio-cultural context in Ghana. The study explores how such influence of religious groups is directly disbursed through their pastors' sway on political culture in the country. The media report how the pastors take advantage of the overt participation of some political leaders in religious activities, as well as how their involvement with educational and financial institutions appear to grant them and their groups an enviable presence in the public sphere and favoured access to the corridors of state power.

\section{Theoretical Background}

Ghana's new churches do not want to simply acquiesce to the position of preaching the word of God as quiet pious groups but rather seek to engage society as an overarching force that exerts influence on the establishment, thereby engaging in an alternative ideology. This means that the cultural messages emitting from these churches constitute an alternative ideology, which is to say they seek to "influence governance" (interview granted by Rev. Dr. Michael Perry N.O. Tettey, Deputy General Secretary, ICGC, 18 April 2018) rather than simply proclaim the gospel and its preferential option for the poor. This alternative propels the churches to the echelons of power vis-à-vis the state, as defined by the dominant ideology of state political culture.

Clifford Geertz is "a notable advocate and an influential definer" (LaCapra 1988, p. 377) of culture. In his "Ideology as Cultural System" Geertz "applied his general concept of culture to the particular problem of ideology", criticizing "the reductionism of both the Marxist notion of ideology in terms of interest and the functionalist notion in terms of tension-management (or the reduction of "strain" (LaCapra 1988, p. 377). Huaco (1971, p. 248) has, however, criticized this "two-factor conception of ideology (as falsity and as social role)", offering a third element of ideology, duplication or isomorphism, besides the "interest" theory and "strain" theory. Huaco argues that isomorphism is more than a mere duplication; "it also sets the limiting assumptions of a class or an epoch". The three-factor notion of ideology, thus, allows sociologists to refrain from "a restricted usage of ideology as falsity and role" since "the isomorphic factor in ideology suggests that in every society, the 'common-sense' view of the world is one structured in terms of ideological myths" (Huaco 1971, p. 254). Such a structure makes the notions of a dominant ideology and an alternative ideology in society comprehensible. This study dissects the strategies and motivations of Action Chapel and ICGC to underscore their efforts to access and influence political society as an alternative ideology to the state's dominant secular ideology.

Comaroff and Comarof (2001, p. 3) extend this ideological argument by situating it within the framework of public culture "to animate further debate on the enigmatic nature of millennial capitalism, and also on its implications for theorizing history and society at the start of the 21st century", wishing "to characterize our current moment-as an age of death (of ideology, politics, the subject) or rebirth (of the spirit of Marx, Weber, the two Adams, Ferguson and Smith)—ours are perplexing times". Thus, the death and rebirth of Marxist ideology, for example, continues to characterize public culture today, which inures to the benefit of the "millennial capitalism of the moment: a capitalism that presents itself as a gospel of salvation" (Comaroff and Comarof 2001, p. 2) upon which, after all, the prosperity gospel of Pentecostalism thrives. Prosperity gospel invites the believer to trust in the saving power of Jesus Christ, who suffered, died and was resurrected to save human beings. Hence, in prosperity gospel lies the assurance of one's spiritual and material victory. It follows that the spiritual power of this faith 
makes possible the conquering of the temporal order, which is why the church can influence social order, including the state. The wealth and power generated from this religious movement catapults it into the public sphere, having garnered renewed confidence to influence state ideology not only in Ghana but also in particularly similar societies in the global South which share larger structural and historical characteristics.

Marshall (2009) asserts that Pentecostalism acts to assure Nigerians of political and religious salvation, a reality which Obadare (2018) extends in showing how Pentecostalism is usurping state power in the same country, Africa's largest democracy, to the extent of demobilising civil society. His vivid description of the Nigerian case corroborates Acheampong (2018) argument that Pentecostals in Ghana ${ }^{1}$ have moved out of their previous "enclave community status" to a novel "sustained political engagement" status wrought in "prophetic politics", giving credence to my contention that Pastor Mensa Otabil and Archbishop Duncan-Williams see themselves as fulfilling that prophetic role in the alternative ideology they offer vis-à-vis that of the state. This action is constructed through their public discourse to assuage public opinion that constrains state dominant ideology, with the dominant and alternative ideologies hereby defined as systems of governance.

In Gifford (2004, p. 48) view, "Faith Gospel, the Gospel of Prosperity, or the Health-Wealth Gospel” emanates from Pentecostal Christianity, which implies success in almost every field of life, economic, political, social. As churches of the Pentecostal-charismatic tradition, Action Chapel and ICGC are steeped in prosperity gospel theology, meaning the gospel of health and wealth. This theology extends the "gospel" the churches preach into an alternative ideology that seeks to participate in, influence or even exact the power of the state's dominant ideology of secular governance. As seen earlier, Karl Marx's work helps us understand that status and compensatory ideology (Huaco 1971) help to make sense of Pentecostal churches traversing the social class configuration in Ghana, giving the new churches an alternative voice to influence dominant politics. Building an overarching force to wield influence on the centre of power, the churches emit cultural messages characteristic of an exerting force on the establishment while at the same time profiting from the prestige and privileges such power bestows. I will show in the paper how the leaders' actions and pronouncements in the Ghanaian public sphere exert such force on the establishment.

\section{Method}

Action Chapel and ICGC were selected purposively according to their age and influence in the Ghanaian public sphere. Purposive sampling was an effective means of identifying specific religious groups whose spokespersons were interviewed (Bryman 2008). The images of the churches depicted in the media provided a major means of knowing and understanding how the churches operate. The media have their limitations in presenting objectivity, which is why as many and varied reportages as possible, as well as sources, were employed to complement each other. Seven media sources with a large following in Ghana and outside Ghana were selected and their content analysed. These included Citi Business News, Ghana New Agency, Graphic Online, Myjoyonline.com, Peacefmonline.com (2014), Radioxyzonline.com and Daily Guide. To counterbalance these media sources, one prominent leader each and six members each of the churches themselves were interviewed in fieldwork for the study. The prominent leaders were the Deputy General Secretary of ICGC and a Bishop at the Headquarters of Action Chapel, who were both chosen in view of their being at the centre of authority of their religious groups (it was not possible to interview the founders), while the members were chosen randomly. Similar questions were addressed to them in in-depth interviews to ascertain their views on their church's influence on the public sphere and governance. The questions included the following: "What would you say is the role of your church in the Ghanaian society?", "In what way would you

1 I am familiar with the scholarly works of major scholars in the field, such as Birgit Meyer, but have chosen to focus on more recent scholars whose works speak more closely to my topic. 
say that your church contributes to the country's socio-economic development?", "What is your view on church/state relations?" and "In what practical ways would you say your church and its leaders influence politics in Ghana?". The interviews were held in Accra with members and leaders of the selected churches between April and May 2018. The study is thus a qualitative analysis of information gathered on these churches from both within and without in order to guarantee a balanced view.

The study draws on my ongoing research into Pentecostal-charismatic churches in Ghana and their transnational engagement since 2007 (Okyerefo 2008). Beginning from February 2007, I have conducted fieldwork in Accra, deploying interviews and participant observation in addition to a perusal of media reports and written documents using content analysis (Okyerefo 2011). I also follow the activities of these religious groups even outside the framework of formal fieldwork, with particular analysis on their media presence in the country, and also their transnational networks in the global North (Okyerefo 2008, 2014). Content analysis of media is necessary, in addition to interviews, as the church leaders and members themselves do not easily admit to yearning for political influence. While the study will draw on two main cases to illustrate the said political influence, Archbishop Duncan-Williams' "cedi prayer" and Pastor Otabil's "Capital Bank saga", in view of the huge public discontent they generated, other examples will be used to buttress the argument, pointing to a developing system of public culture akin to an ideology surrounding these religious groups' nibbling at the centre of power. The "cedi prayer" touched on the heart of the nation's economic woes while the "Capital Bank saga" hinged on state law and affected the very livelihoods of people.

I argue in the paper that, although the effort expended by religious groups in Ghana to access and influence political power is not a historical novelty, sectional ambitions in respect of political access and influence have nevertheless recently gained ascendancy. This development is in response to the relatively rapid and large-scale growth of religious diversity across the nation and within its growing conurbations as a result of the proliferation of Pentecostal-charismatic churches. The scramble of Pentecostal-charismatic churches for access and influence is most clearly manifest in organizational strategies and the pronouncements of their leaders through the medium of the media. To this end, I assess the strategies and motivations of Action Chapel and ICGC in striving to access and influence political society in Ghana. Thus, the words and actions of perhaps the most influential Pentecostal-charismatic pastors (Pastor Otabil and Archbishop Duncan-Williams) are mostly the focus of this work since they are well known and central to the subject of the study.

Archbishop Nicholas Duncan-Williams is certainly a pioneer founder of a Pentecostal-charismatic church that wields a good deal of influence in Ghana. His Action Chapel is a household name in Ghana. His flamboyant life style and comments on issues of a controversial nature keep him constantly in the media. His Dominion University also belongs to the growing number of private universities in Ghana seeking to make their mark in the sphere of education.

Pastor Mensa Otabil is one of the most influential Pentecostal-charismatic leaders in Ghana. Founder and General Overseer of ICGC, his list of credentials include the setting up of a private university in Ghana, Central University-one of the few such private institutions to obtain a charter from the state. Pastor Mensa Otabil cherishes a Pentecostal faith that speaks to Africa's social needs, believing that the greatest potential of Africans is yet to be realized. Consequently, he seeks to promote a rigorous intellectual debate and teaching on various subjects relevant to this development. To this end, his weekly Living Word broadcast programme is listened to by many Ghanaians.

\section{Political Access and Influence}

As seen earlier, "Ghana was conceived as a secular state". However, "Christianity became the primary religion during the era of colonial rule", underpinning "many new laws guiding the State ever since" (Dovlo 2005, p. 629). Consequently, colonialism bequeathed Ghana with the historic Christian churches (Anglican, Methodist, Presbyterian, Roman Catholic) that wielded considerable influence on the Ghanaian public sphere. This was achieved largely through the schools they established and the moral authority they exerted on the Ghanaian public, thereby gradually eroding Traditional African 
Religion. The influence of these historic churches is evidenced, for example, in their reaction to the Religious Bodies (Registration) Law of 1989 (PNDCL 221). The fact that the Christian Council of Ghana (CCG) and the Ghana Catholic Bishops' Conference (GCBC) could stand up to the military government and refuse to register (Dovlo 2005, pp. 642-43) indicates how powerful these religious groups were. The numerous communiqués or pastoral letters of the GCBC or CCG also further support the effect of their influence. Moreover, President Mills, former Presidents Kuffuor and Rawlings, and several ministers and parliamentarians all attended the Catholic Church's second plenary assembly of the Regional Episcopal Conferences of West Africa (RECOWA), held in Accra, Ghana, from 22 to 29 February 2016.

As mentioned above, new players have since entered the field, changing the religious scene and deploying new strategies to exert influence on the Ghanaian polity. Dovlo $(2005$, p. 644) asserts that many "new religious movements, especially 'charismatic' Churches", began to proliferate "in Ghana beginning in the late 1970s", drawing "their membership mainly from the older churches", thereby changing the religious scenario remarkably. The greatest change took place in the urban areas. The Greater Accra Region, the most densely populated region with approximately 1236 persons per square kilometre (Ghana Statistical Service 2012, p. 2), undoubtedly has a remarkable religious landscape. The growing presence of Pentecostal-charismatic Churches is posing a challenge to the historic Christian denominations, both numerically and in terms of their visible presence in the public sphere.

The 2010 Population and Housing Census Report shows that the Roman Catholic Church remains the single religious denomination with the largest following in Ghana, with 3,230,996 adherents, comprising $13.1 \%$ of the Ghanaian population. The Protestant denominations together have 4,534,178 adherents, comprising $18.4 \%$ of the population, while the Pentecostal-charismatic groups in total, with their $6,980,792$ adherents, form $28.3 \%$ of the Ghanaian population. The Pentecostal-charismatic Churches have 1,786,519 adherents in Greater Accra alone, while there are only 892,537 Protestants and 300,446 Catholics in the same region (Ghana Statistical Service 2012, p. 40). This reality also supports the argument that Pentecostalism is largely an urban phenomenon. At the same time, however, the trend shows its growing presence in the rural areas as well.

Undoubtedly, this growing numerical presence of Pentecostal-charismatic churches gives them the confidence to exert themselves in the public sphere. Their mega churches are visible, especially in the cities, while they have a growing media presence. To "found mega churches is to found powerful constituencies", while the "transnational character of these churches promotes foreign earnings that are ploughed into development projects such as schools and hospitals" (Okyerefo 2011, p. 285), even universities, in a true spirit of the historic churches. Bishop Dag Heward-Mills of the Lighthouse Chapel International contends that megachurches pose a challenge to governments that are constantly looking for votes. He says mega churches mean "more contacts and 'connections' as many people can find jobs through the church" (Heward-Mills 1999, pp. 16-17). Added to their physical presence is their media presence. Asamoah-Gyedu (2007) underscores the huge media presence of Pentecostalism, characterising this brand of Christianity as a constantly changing reality that seeks to take full advantage of new technology.

In the style of the mega church and executing their mission through the media, it can be argued that Pentecostal-charismatic churches are making their presence felt in Ghana by affirming themselves in the corridors of power. Furthermore, while Pentecostal pastors are increasingly taking centre stage in making their presence felt in Ghanaian society, politicians are seen more and more in their churches-maybe to catch voters, as Bishop Dag Heward-Mills observes above? Indeed, the courtship between Pentecostal leaders and politicians appears to be a symbiotic one, with leaders from both spheres seeking to operate in each other's field of influence-the one to court votes and the other to share in political sway. In the Daily Guide headline of 3 December 2013 (Daily Guide 2013) Archbishop Nicholas Duncan-Williams told President John Dramani Mahama "Free The Money", referring to the economic difficulties in the country. President Mahama was attending a church service at Action Chapel-where the politicians go, there follows the press. This does not only include Ghanaian 
politicians-some foreign envoys have also discovered this new "wave", so that even though the late president Mandela was Methodist by religious affiliation and had a Methodist minister celebrate his funeral in his ancestral home of Qunu in South Africa, the South African High Commissioner in Ghana organized a special memorial service for Mandela at Archbishop Duncan-Williams's Action Chapel and not in any Methodist Church parish in Accra. Again, the president of the republic, John Mahama, was in attendance, as well as a "high patronage from former President Jerry John Rawlings, politicians, members of the Diplomatic Corps and Christians from other churches who joined the congregation of the host church to celebrate the life of the late South African leader" (Graphic Online 2014b).

Ghanaian presidents' flirting with Pentecostal-charismatic pastors caused a tidal wave during the regime of the late President Professor John Evans Atta Mills, a Methodist by Christian affiliation, who became enamoured with Prophet Temitope Balogun Joshua of Nigeria, popularly called T.B. Joshua. The media in Ghana reels with anecdotes on President Atta Mills' relationship with T.B. Joshua, who is said to have been the personal pastor-physician of the president and had unrestrained access to the seat of government, Christianborg Castle, whenever he wished. President Atta Mills is claimed to have testified that T. B. Joshua prophesied his ascent to the presidency (The PM News, Nigeria 2009). The president is also said to have paid several visits to the prophet's church in Lagos, in search for a cure to his ailment. In short, his relationship with T.B. Joshua generated a lot of media discussion in the Ghanaian public sphere, meeting with consternation in large segments of Ghanaian society. His critics felt that the president should have concentrated on exhibiting strong leadership and fixing the problems of the nation rather than trotting to pastors. Despite Ghana's characteristically huge religious public, the ambivalence of President Atta Mills' public display of religiosity and acquiescing to pastors met with disquiet. Indeed, public reaction to such attitudes is becoming increasingly so, especially when pastors pontificate on aspects of life which experts question.

A typical case in point is what is now referred to as Duncan-Williams' "cedi prayer". On Sunday, 2 February 2014 (Graphic Online 2014a), Archbishop Nicholas Duncan-Williams prayed that God should avert the depreciation of the Ghanaian currency, the cedi, and the spiral downturn of the economy at large: "I hold up the cedi with prayer, and I command the cedi to recover and I declare the cedi will not fall; it will not fall any further. I command the cedi to climb. I command the resurrection of the cedi. I command and release a miracle for the economy" (Radioxyzonline.com 2014b). While this prayer and his subsequent response to his critics is a message that strikes a chord with what some politicians possibly wished to hear in the face of mounting criticism regarding the government's management of the economy, Nicholas Duncan-Williams was severely criticized by a section of the public, including a few politicians. When criticized that "religion or prayer had no place in economic management and that the Archbishop should leave the management of the economy to economists", Duncan-Williams responded that "while he had no grip on the management of the national economy, he was a spiritual man whose concern was for the growth and prosperity of the country" (Graphic Online 2014a). He stressed that nobody had asked him to pray. However, "as a spiritual man, and looking at what is going on in other countries and the suffering of people... I'm praying from my perspective because I am a leader and I deal with people and I see what the people are going through". He went on to list his accomplishments: "I have a drug rehabilitation centre, an orphanage, I'm building schools which were under trees and churches all over the country that I care about. I know that if the economy gets well, it is in the interest of all of us. So to pray for the economy to get well, praying for the well-being of the economy and the cedi is Biblical and a good thing. If anybody is not managing the economy or the currency well, that is not my problem. I leave that to those in authority and those who voted them into office to deal with it. But that should not deter me from praying" (Graphic Online 2014a).

Bishop Samuel Awuku Opare-Lokko of Action Chapel, whom I interviewed on 17 April 2018, said Archbishop Duncan-Williams' other title is the "Apostle of Prayer". He engages in "strategic prayer" in response to any situation or human predicament, which he (the Archbishop) believes God is capable 
of handling. Another member of the church interviewed (wishes to be anonymous) on 29 May 2018 believes that Action Chapel "complements the state". She explained further:

I think Action Chapel has been instrumental in politics, especially during the recent election petition hearing, especially when we got to a brink of collapse because of who has won the election and who has not won. The Archbishop was so key. So, Action Chapel through the Archbishop was part of the eminent leaders who brought all sides together including the Electoral Commission to ensure that.

Her comment was in reference to the dispute which ensued between the NPP and the NDC after the 2012 elections when the NPP brought the case to court.

Archbishop Duncan-Williams himself argued that "church and the state were inextricably linked and that for the past one hundred years Ghana's churches have played key roles in the development of the country". For him, "God is the governor of nations", "Abraham Lincoln, one of the greatest American presidents, declared fasting and prayer on three different occasions—on the last Thursday of September 1861, 30 March 1863 and in August 1864 for issues including national peace, national repentance and for people who held positions of authority, respectively" (Graphic Online 2014a). The Archbishop must be right in expressing this view as the US constitution was inherently based on Christian precepts. To this end, his view smacks of a church-state symbiosis in which dominant and alternative ideologies could influence and profit from each other, including a share in the power of the state. This is not uncommon, however, as the case of countries such as Saudi Arabia shows.

Duncan-Williams' "cedi prayer" re-kindled a discussion on the Ghanaian economy, with the Graphic newspaper highlighting the fact that 2013 was one of the worst years in recent history regarding the performance of the currency - the year closing with a 17\% slump of the cedi against the dollar. This would lead to the Bank of Ghana pumping \$20 million into critical areas of the economy as part of efforts to shore up the cedi. The paper also reminded readers that "the cedi's battle of survival against the major trading currencies-the dollar, euro and the pound sterling-is part of the global crisis that has seen countries including Argentina, Turkey, South Africa, Brazil, India, Ukraine, Venezuela and Mexico struggle to keep their currencies afloat" (Graphic Online 2014a).

The staunchest critic of Duncan-Williams' prayer was Dr. Tony Aidoo, Head of Policy Monitoring and Evaluation at the office of the president. Describing Duncan-Williams' action as "comic relief" (Myjoyonline.com 2014), he believed that "attitudinal change and a change in the structure of the economy are the requirements to stabilise the cedi and not prayers". However, others rose to the defence of the pastor or continued to prophesy regarding the currency. Rev. Titi Offei believed Tony Aidoo's comments were, at best, hypocritical. He could not reconcile Tony Aidoo's silence over the late President John Atta Mills' invitation to pastors to pray at the Castle-the seat of government-every morning, with his critique of Duncan-Williams. Rev. Titi Offei was also critical of Tony Aidoo for saying nothing about politicians running to churches and to pastors for prayers prior to elections only to turn away from the said pastors when they win power.

It is against this backdrop that the Bank of Ghana, as per its directive reference BG/GOV/SEC/2014/02 to all banks, revised its rules for operating foreign exchange accounts (FEA) and foreign currency accounts (FCA) with effect from 5 February 2014, as part of its measures to stabilise the performance of the cedi (Bank of Ghana 2014). While this directive may have nothing to do with the prayers and pronouncements of the Pentecostal pastors under discussion, it does point to the fact that these individuals make it a point to speak to issues affecting the nation. Duncan-Williams' immediate and public reaction to the directive points to his determination to continue to play a key role in the public sphere. On Sunday, 9 February 2014, his church (Radioxyzonline.com 2014b) ordered congregants "to stop issuing dollar cheques for offertories, tithes and other payments" and issue "only cedi cheques". Duncan-Williams publicly called on his church to adjust to the measures for practical reasons as it was unlikely the Bank of Ghana would honour foreign currency cheques. He would go on to be become a government appointee to serve on the Council of the University of Ghana, 
the nation's premier university, from 2 August 2016 to 7 January 2017 (Registry of the University of Ghana 2018) when the council was automatically dissolved with the assumption of power by the newly-elected NPP. It should be noted that he was appointed by the NDC government of President John Mahama. Archbishop Duncan-Williams, however, would seem to continue to enjoy the respect of some high-ranking officials of the new NPP government of President Nana Addo Dankwa Akufo Addo. Indeed, as I arrived at the premises of his cathedral, university and office complex for my research interviews on 17 April 2018, I was closely followed by the motorcade of the Inspector General of Police (IGP), David Asante-Apeatu, who went into a closed-door meeting with the Archbishop and was still there when I left after conducting a one-hour interview. When I made a friendly remark to my interviewee, Bishop Samuel Awuku Opare-Lokko, regarding what a "very important person" his Archbishop must be for the IGP to visit him, he responded with elation: "this answers what your research is seeking to know about Action Chapel's influence on political culture". Obviously, Bishop Samuel Awuku Opare-Lokko, as a leader in the church, must be conscious of his church's determination to be that alternative voice that should constantly nibble at the state's own.

In a similar vein, Pastor Mensa Otabil's nibbling with the power of government is exemplified in the Capital Bank saga. Pastor Otabil was Chairman of the Board of Capital Bank, which collapsed in 2017. The bank is purported to belong to a consortium including him and a number of his church members, some of whom were shareholders and board members at the same time. The published memo of the former CEO (Former Capital Bank CEO's 2014 memo) predicting the collapse of the bank reveals unorthodox operations of the bank that were obviously not addressed (Chief Executive Officer 2017), despite the CEO's stark warning. This evidence is a further reason that some Ghanaians would be surprised that, in spite of what verges on financial malfeasance, the Ghanaian public sphere is yet to learn of the truth in the Capital Bank Saga and whether any individuals found culpable would face disciplinary measures. Given the purported interest of the Bank of Ghana to issue a GH $2 b n$ bond to clear Capital Bank and UT bank (CitiBusiness NEWS 2018), it is natural for the tax payer to be concerned. Members of the ICGC, however, believe their mission to be influencing society positively. One member interviewed on 23 May 2018 said that "ICGC in a way is trying to develop a mind-set in Africans that they are capable in doing things on their own. So that we don't become so much dependent on foreign government so that every time we want to sit down and be expecting the foreign government to come". This thinking should be credited to Pastor Otabil, an astute motivational speaker who is skilled at educating his church members and the public. His strategy has propelled ICGC's political engagement into an alternative ideology, which thrusts the church into the limelight. Indeed, he himself has become such an eminent Ghanaian, warranting his membership on the first Board of the National Peace Council of Ghana in 2011, a statutory board.

In Ghana, pastors simply dare to pontificate or make pronouncements on anything, from economic to security matters-areas one would think are the preserve of the secular state and its experts. The pastors make such pronouncements usually in their churches, during their sermons, and in the public sphere, where the media is present to carry them into the outside world. Indeed, the failure of the state in the provision of jobs and social services, as well as giving the citizenry a sense of purpose, for example, constitute some of the reasons why people look to churches for leadership. The examples in the paper corroborate how, in common parlance in the Ghanaian banking sector, some individuals are profiled as Politically Exposed Persons (PEP). The founding of churches constitutes an area of public life in which the state has failed to provide regulation, which is why any person, irrespective of qualification, can found a church. In other words, in Ghana, one does not need to have theological training to found a church. It solely devolves on any individual feeling of being "called" for the purpose or perhaps "hearing voices" of commission. Consequently, this is an aspect of the Ghanaian public sphere where individuals confer titles on themselves-titles that seem to be recognized by society. In no other area of public life is this possible, yet service is sought by members of the public in such religious institutions-a service which is rendered and at the same time opens up avenues for abuse. 
When pastors make pronouncements in the interest of the government, their action is well received by politicians. President John Dramani Mahama is said to have proclaimed "Don't tag religious leaders as partisan" (Radioxyzonline.com 2014a). In fact, the President would go so far as to institute a "National Week of fasting, prayer and thanksgiving", beginning from 2014, to be "organised by the Christian community, in collaboration with the government. A meeting to discuss the maiden programme took place at the Banquet Hall of the Flagstaff House "when the President hosted the senior clergy to a breakfast meeting" (Graphic Online 2014c). By the same token, one of the major projects President Akufo-Addo sought to implement soon after taking office was that of constructing a National Interdenominational Cathedral-a project that has met with much controversy in the country in view of the principle of the church-state separation required in a modern democracy.

By their actions and pronouncements, pastors like Archbishop Duncan-Williams and Pastor Otabil are keenly aware that the ultimate power they wield results from setting themselves as an alternative ideology against the dominant ideology of state power if only to exact part of it. Thanks to the prosperity gospel-the health-wealth theology they propound-their churches have become immensely wealthy, thereby enjoying prestige and influence, but also critique in Ghanaian society. The penultimate aspect consists of sharing in the state's power of governance or presenting themselves as an alternative to it. Thus, the churches, in part, assume the structures of the state. The main examples enumerated in this study—-the "cedi prayer" and the "Capital Bank saga"—as well as their various corollaries are indicative of what Comaroff and Comarof $(2001$, p. 2) term the "millennial capitalism of the moment: a capitalism that presents itself as a gospel of salvation". The prosperity gospel of Pentecostalism is a brainchild of this development, whose fruits include wealth, power and prestige-cherished values which Pentecostal-charismatic churches in Ghana seek to project into the limelight. The desire to influence and set themselves against or act in tandem with the state apparatus, I argue, consists of an ideological system which presents an alternative to the dominant state ideological power.

It is not uncommon for founders of some Pentecostal-charismatic churches in Ghana to be referred to as "General Overseer", which is akin to the "Commander in Chief" of the state. Their lifestyles exemplify this status when they move about under the protection of their own security agents and their wives are referred to by church members as "First Lady" of the church, which suggests that the founder is "president". This verges on the tendency of Pentecostal-charismatic church leaders to operate as the president of an African nation-state. In my interaction with Action Chapel members, they referred to Archbishop Duncan-Williams informally as "papa", while some ICGC members call Pastor Otabil "the Founder", although they themselves said he dislikes titles, preferring simply the prefix "pastor". Consequently, it lies within the competence of the "founder", the "president" of the church, to call a press conference as Pastor Otabil did in 2012 or for the IGP to pay a courtesy call on Archbishop Duncan-Williams for a closed-door meeting on 17 April 2018. Again, being in the good books of a particular government could earn a pastor the position of member of a University Governing Council, specifically a government appointee on the Council. To what extent will clients of the collapsed Capital Bank receive justice from the dominant ideology? This question can only be answered at the end of due process.

\section{Conclusions}

The concrete strategies and motivations employed by the leaders of Action Chapel and ICGC are in consonance with prosperity gospel churches. Prosperity gospel essentially positions itself against the centrality of the cross in the path of salvation as espoused by most historic churches and is thus a significant factor in the undue political influence sought by leaders of Pentecostal-charismatic churches. State dominance is wrought through competing ideologies-the overriding one controls social actors at any point in time. However, the actions and strategies of Action Chapel and ICGC point to the fact that they can meet state ideology with an alternative ideology in the prosperity-driven capitalistic culture of the moment. Such thinking makes it possible for Archbishop Duncan-Williams to believe 
that praying for the cedi would make Ghana succeed where the state had failed to fix the economy, or at least that his action could complement the efforts of the state. Again, a similar conviction makes Pastor Otabil call a press conference to influence the supposed narrative of the state or people closely working for it. By the same token, by being close with state actors, Archbishop Duncan-Williams gets to serve on the University of Ghana Council as government appointee while Pastor Otabil appears to enjoy less state torment in the face of leading a financial institution to its collapse. The churches find in an alternative ideology a confidence to tread even beyond their competences or areas of expertise by trusting God, who can make everything possible through them (see Okyerefo 2006/2007, 2011).

An important discovery of the study is the fact that the state apparatus, with its dominant ideology, is difficult to match with an alternative. The context of Pentecostal-charismatic Christianity within the increasingly diverse socio-cultural context in Ghana is awash with prosperity gospel, which is characterised by the capitalistic culture of the moment. The implications of this research in understanding specifically Pentecostal-charismatic engagement thus point to a further blurring of church-state separation within the scramble for the centre. Any desire for power easily makes the church oscillate between pushing an alternative ideology and an association with the dominant ideology. The courtesy call paid by the IGP on Archbishop Duncan-Williams is an example of this power play between the dominant ideology and alternative ideology. Compared to those of other religious communities, a moral alternative demands courage and patience, which means that influencing state ideology will most likely be a long-term project, which would suggest itself to be the approach of the historic churches.

The strategies of Action Chapel and ICGC to sustain the said alternative ideology thus include the following: first, a strong media presence, typified in Pastor Otabil's press conference or his weekly teaching "the Living Word"; second, their discourses on economic, social and political issues as exemplified in Archbishop Duncan-Williams' "cedi prayer" or Pastor Otabil's involvement with Capital Bank, alongside the employment their universities or other institutions offer citizens; third is their direct personal engagement with government officials and the general invitation of government officials to their churches. The efforts Action Chapel and ICGC expend on all these actions send out a strong message that they are key actors that cannot be ignored by the state.

Funding: This research received no external funding.

Conflicts of Interest: The author declares no conflict of interest.

\section{References}

Acheampong, Fredrick. 2018. Pentecostals and Politics in Ghana's Fourth Republic: From Enclave to Engagement. Ph.D. Thesis, Victoria University of Wellington, Wellington, New Zealand.

Asamoah-Gyedu, Kwabena Johnson. 2007. “Get on the Internet!” Says the LORD: Religion, Cyberspace and Christianity in Contemporary Africa. Studies in World Christianity 13: 225-42.

Bank of Ghana. 2014. BOG Directive-Foreign Account Operations. Accra: BG/GOV/SEC/2014/02 to all Banks, 2. Bryman, Alan. 2008. Social Research Methods. New York: Oxford University Press.

Chief Executive Officer. 2017. Urgent Action to Salvage the Reputation and Fortunes of First Capital Plus Bank: August 11, 2014 Board Memo to Chairman and Members, Board of Directors. August 16. Available online: http://citifmonline.com/2017/08/16/former-capital-bank-ceos-2014-memo-predicting-collapse/ (accessed on 27 May 2018).

CitiBusiness NEWS. 2018. BoG Justifies GHф 2bn Bond Issue to Clear UT. Accra: Capital Banks Liabilities.

Comaroff, Jean, and John L. Comarof. 2001. Millennial Capitalism: First Thoughts on a Second Coming. In Millennial Capitalism and the Culture of Neoliberalism. Edited by Comaroff Jean and John L. Comaroff. Durham and London: Duke University Press, pp. 1-56.

Daily Guide. 2013. Free the money_Duncan Williams tells Mahama. Daily Guide, December 3.

De Witte, Marleen. 2003. Altar Media's Living Word: Televised Charismatic Christianity in Ghana. Journal of Religion in Africa 33: 172-202. [CrossRef] 
Dovlo, Elom. 2005. Religion in the public sphere: Challenges and opportunities in Ghanaian lawmaking, 1989-2004. BYU Law Review 3: 629-58.

Ghana Statistical Service. 2002. 2000 Population and Housing Census: Summary Report of Final Results; Accra: Sakoa Press Limited.

Ghana Statistical Service. 2012. 2010 Population and Housing Census Report; Accra: Sakoa Press Limited.

Gifford, Paul. 2004. Ghana's New Christianity: Pentecostalism in a Globalizing African Economy. Bloomington: Indiana University Press.

Graphic Online. 2014a. Duncan-Williams Defends Cedi Prayer. Graphic Online, February 4.

Graphic Online. 2014b. Let's End Acrimony along Ethnic Lines-Mahama. Graphic Online, January 27.

Graphic Online. 2014c. Week of Fasting, Thanksgiving to be Instituted. Graphic Online, March 18.

Hastings, Adrian. 1994. The Church in Africa: 1450-1950. Oxford: Clarendon Press.

Heward-Mills, Dag. 1999. The Mega Church. Accra: Parchment House.

Huaco, George A. 1971. On Ideology. Acta Sociologica 14: 245-55. [CrossRef]

LaCapra, Dominick. 1988. Culture and Ideology: From Geertz to Marx. Poetics Today 9: 377-94. [CrossRef]

Marshall, Ruth. 2009. Political Spiritualties: The Pentecostal Revolution in Nigeria. Chicago: University of Chicago Press.

Myjoyonline.com. 2014. Make Duncan-Williams Next President to Solve all Our Problems_Pratt. Myjoyonline.com, February 4.

Obadare, Ebenezer. 2018. Pentecostal Republic: Religion and the Struggle for State Power in Nigeria. Chicago: University of Chicago Press.

Okyerefo, Michael Perry Kweku. 2006/2007. Trust God! Religious expression at the University of Ghana. Ghana Social Science Journal 3-4: 1-2, 18-32.

Okyerefo, Michael Perry Kweku. 2008. Ausländer! Pentecostalism as Social Capital Network for Ghanaians in Vienna. Ghana Studies 11: 77-103.

Okyerefo, Michael Perry Kweku. 2011. The Gospel of Public Image in Ghana. In Christianity and Public Culture in Africa. Edited by Harri Englund. Athens: Ohio University Press, pp. 204-16.

Okyerefo, Michael Perry Kweku. 2014. Transnational Dynamics in African Christianity: How Global is the Lighthouse Chapel International Missionary Mandate? Journal of Africana Religions 2: 95-110.

Okyerefo, Michael Perry Kweku. 2018. Philanthropy as Image Politics in Ghana's New Churches. Journal for the Study of the Religions of Africa and Its Diaspora 4: 99-112.

Otabil, Mensa. 2012. Press Statement. Adom News, November 12.

Peacefmonline.com. 2014. Rev Korankye Ankrah Warns of “Wicked People" Infiltrating Ghana. Peacefmonline.com, January 2.

Radioxyzonline.com. 2014a. Don't Tag Religious Leaders as Partisan-Mahama. Radioxyzonline.com, March 17.

Radioxyzonline.com. 2014b. Duncan-Williams Orders Congregants to Pay Offertory in Cedis. Radioxyzonline.com, February 9.

Registry of the University of Ghana. 2018. Archbishop Nicholas Duncan-Williams' Term on the Council of the University of Ghana. Personal communicatio, May.

The PM News, Nigeria. 2009. 'T.B. JOSHUA PREDICTED MY VICTORY - GHANA'S LEADER'. Available online: https://www.scoan.org/blog/2009/06/04/t-b-joshua-predicted-my-victory-ghanas-leader/ (accessed on 10 December 2019).

(C) 2019 by the author. Licensee MDPI, Basel, Switzerland. This article is an open access article distributed under the terms and conditions of the Creative Commons Attribution (CC BY) license (http://creativecommons.org/licenses/by/4.0/). 